DOI: $10.21802 / \mathrm{artm} .2020 .3 .15 .135$.

UDC 617.55-003.92-007.43-089

\title{
INCREASING SAFETY OF SURGICAL INTERVENTIONS IN PATIENTS WITH VENTRAL AND INCISIONAL HERNIA UNDER COMORBIDITY CONDITIONS WHEN PERFORMING DIFFERENT TYPES OF OPEN HERNIOPLASTY
}

\author{
V.I. Piatnochka, I.Ya. Dziubanovskyi, A.M. Prodan
}

\section{Horbachevsky Ternopil National Medical University, Department of Surgery of Educational and Scientific Institute of Postgraduate Education, Ternopil, Ukraine, ORCID ID: 0000-0002-7417-4797, ORCID ID: 0000-0001-8852-3938, ORCID ID: 0000-0002-6052-192X, e-mail: vladymyrpiatnochka@gmail.com}

\begin{abstract}
In the period from 2001 to 2017, 1419 patients with ventral and postoperative ventral hernia were operated on. The unsatisfactory results of the surgical treatment of this pathology were due to a number of disadvantages: the choice of an inadequate method of hernioplasty in a specific clinical situation, an incomplete revision of the muscle-aponeurotic layer of the anterior abdominal wall, especially in patients with postoperative veterinary hernias, concomitant syndrome of undifferentiated connective tissue dysplasia and obesity, and weak points, the wrong choice of the type of mesh implant ("light" or "heavy" polypropylene mesh) and its size, the choice of an inappropriate type of suture material, as well as the high invasiveness of surgical intervention. Based on the given causes of complications in the operated patients with a high risk of their development, we have made a technical improvement of the existing methods of hernioplasty and development of new ones, which significantly reduced the number of postoperative complications and increased the safety of performing surgical interventions in patients with ventral and postoperative ventral hernia.
\end{abstract}

Purpose. Based on the results of the analysis of surgical treatment of patients with comorbid conditions of primary and incisional ventral hernias to develop technical prerequisites for improving the safety of surgical interventions in this category of patients.

Methods. In the period from 2001 to 2017, an in-depth comprehensive clinical-instrumental and laboratory examination of 1419 patients with primary ventral hernia $(\mathrm{PVH})$ and postoperative ventral hernia (PVH) was conducted. The patients were divided into groups according to the periods of surgical treatment of patients. For this purpose, two periods were formed: from 2001 to 2009 and from 2010 to 2017. At the first period, 597 (42.07\%) patients were examined and operated on. These patients formed a comparison group. The main group corresponding to patients who were treated in the period from 2010 to 2017 was 822 (57.93\%) people.

Results. Developed techniques for performing retromuscular allogernioplasty, which were based on controlled visualization of suturing when fixing polypropylene mesh to the posterior leaf of the vagina of the rectus muscle, allowed us to reliably and safely place and secure the implant in the retromuscular space, significantly reduce the trauma and duration of surgery.

Kind of treatment using the mesh allograft with a liposomal complex with included antibacterial and immunosuppressive agents during the operation on the "onlay" method significantly reduced the number of local infectious complications. The location of the PRF membrane over the polypropylene mesh during retromuscular allogernioplasty improved neoangiogenesis at the mesh implantation site, increased fibroblast activity and the formation of collagen fibers around the mesh material, which provided maximum integration of the "light" abdominal wall with polypropylene tissue.

Conclusion. These features of the dynamics of the used methods of surgical interventions and types of polypropylene nets with an individualized approach to each patient were reflected in a significant reduction in the number of both early local and general late postoperative complications, which incresed the effectiveness of surgical treatment of patients with primary postoperative ventral hernias.

Keywords: ventral hernia, incisional hernia, complications, surgical treatment, comorbidity.

Introduction. Surgical treatment of patients with primary ventral hernia (PVH) and incisional hernia (IH) continues to be one of the important problems of abdominal surgery $[5,9]$. The increase in the number and complexity of surgical interventions on the abdominal organs has led to an increase in the number of incisional hernias. It is proved that $60 \%$ of patients with IH hernia are of working age, which determines the problem of treatment of such patients not only as medical but also as social $[10,12]$. Given the results of surgical treatment of
IH, it should be noted a significant percentage of recurrences, which is $4.3-46 \%$. Extensive experience has accumulated today in the surgery of PVH and $\mathrm{IH}$ in the use of various methods of surgery $[1,6]$. The progress of surgery is impossible without constant analysis of complications, without identifying and eliminating their causes, development and implementation of measures to prevent medical errors. Surgical treatment of anterior abdominal wall defects with the use of auxiliary alloplastic materials has become dominant in the last decade. The 
use of surgical mesh in the treatment of ventral hernias has increased up to $95 \%$. Thanks to the success of modern polymer chemical technologies, the interest of surgeons in allohernioplasty has been restored, which has brought herniology to a new qualitative level of development $[4,8]$. Adherence to the principle of non-tension plasty and the use of synthetic materials at the present stage has significantly reduced the number of recurrences in alloplasty of PVH and IH to $2-7 \%$.

Incisional hernia that occurs during the first year, most authors associate with early postoperative complications of the wound and abdomen [7,11]. However, there is a risk of their occurrence, especially in cases where an inadequate method of alloplasty is chosen $[2,3]$.

Rationale for the research. The development of local and general postoperative complications that occur in the early postoperative period in patients with $\mathrm{PVH}$ and $\mathrm{IH}$ under conditions of comorbidity require a detailed analysis of the causes and the development of individualized indications for the choice of surgical intervention.

Purpose. Based on the results of the analysis of surgical treatment of patients with comorbid conditions for primary and incisional ventral hernias to develop technical prerequisites for improving the safety of surgical interventions in this category of patients.

Materials and Methods. On the basis of the Department of Surgery of the Educational and Scientific Institute of Post-graduate Education of Ternopil Town Municipal Hospital No. 2, in the period from 2001 to 2017 an in-depth comprehensive clinical-instrumental and laboratory examination of 1419 patients with primary ventral hernia $(\mathrm{PVH})$ and postoperative ventral hernia

(POVH) was performed. The patients were divided into groups according to the periods of surgical treatment of patients. For this purpose, two periods were formed: from 2001 to 2009 and from 2010 to 2017. In the first period, $597(42.07 \%)$ patients were examined and operated. These patients formed a comparison group. The main group included $822(57.93 \%)$ patients who were treated in the period from 2010 to 2017.

In case of PVH defects M1 in the comparison group and the main group were found $-7(2.45 \%)$ and 15 (4.36\%), respectively; M1-3 - $186(65.03 \%)$ and 225 $(65.41 \%)$, respectively; M3 - $86(30.07 \%)$ and 73 $(21.22 \%)$, respectively. There were no M4-5 defects in both groups among primary hernias. L4 defects were observed in $7(2.45 \%)$ and $31(9.01 \%)$ of the operated in both groups. Defects of other localizations (L1-L3) were not noted.

Analysis of the localization and spread of anterior abdominal wall defects in patients with $\mathrm{IH}$ in the comparison group showed that M1-3 was observed in - 232 (74.60\%), M4-5 - 51 (16.40\%) patients. M1-5 variants were not detected in this group. Defects L1, L2, L4 - 17 (5.47\%). Combined ML defects - are in $11(3.53 \%)$ cases. Instead, in the main group among postoperative ventral hernias $(n=478)$ the following localization and spread of defects of the anterior abdominal wall were diagnosed: M1-3 - 297 (62.13\%), M4-5 - 63 (13.18\%), and variant M1-5 are in this group in 47 (9.83\%) patients. Defects L1, L2, L4 - 23 (4.81\%). Combined ML defects in this group in - are $48(10.05 \%)$ patients. The distribution of types of surgical interventions performed in patients with $\mathrm{PVH}$ and $\mathrm{IH}$ in different periods of the study is given in Table 1.

Table 1

Types of surgical interventions performed in patients with PVH and IH in different periods of the study

\begin{tabular}{|c|c|c|c|c|c|c|}
\hline \multirow[t]{2}{*}{ Types of hernioplasty } & \multicolumn{2}{|c|}{ Comparison group $(\mathrm{n}=597)$} & \multicolumn{2}{|c|}{ Main group $(n=822)$} & \multicolumn{2}{|c|}{ Total $(n=1419)$} \\
\hline & Abs. & $\%$ & Abs. & $\%$ & Abs. & $\%$ \\
\hline Own tissue hernioplasty & 314 & 52.59 & 124 & 15.08 & 438 & 30.86 \\
\hline "Inlay" & 17 & 2.84 & 90 & 10.94 & 107 & 7.54 \\
\hline "Onlay" & 254 & 42.54 & 209 & 25.42 & 463 & 32.62 \\
\hline "Sublay" & 12 & 2.01 & 354 & 43.06 & 366 & 25.79 \\
\hline $\begin{array}{l}\text { "CST" (components } \\
\text { separation technique) }\end{array}$ & - & - & 20 & 2.43 & 20 & 1.41 \\
\hline $\begin{array}{l}\text { "CST" (components sepa- } \\
\text { ration technique) + PPM }\end{array}$ & - & - & 25 & 3.04 & 25 & 1.78 \\
\hline Total & 597 & 100 & 822 & 100 & 1419 & 100 \\
\hline
\end{tabular}

Research results. Evaluation of the research results in both groups of observations was performed taking into account the frequency of general and local wound complications and recurrences in the remote postoperative period. Among all 1419 operated patients, 522 (36.78 $\%)$ persons were diagnosed with local early postoperative complications. General complications were in 76 (5.36 $\%$ ) patients. In the comparison group, local complications occurred in $311(52.09 \%)$ patients, and in the main group - were in $211(25.67 \%)$ patients. The same trend was observed in the distribution of general complications: 53 $(8.88 \%)$ and $23(2.79 \%)$, respectively. Late local com- plications were detected in $221(37.02 \%)$ and 115 (13.99\%) cases, respectively.

Own tissue hernioplasty in the period 20012009 was performed in $314(52.59 \%)$ patients. The largest share of autoplasties was observed in patients with umbilical hernia $86(27.39 \%)$, white line hernia - 74 $(23.57 \%)$ and diastase of the rectus abdominis -68 $(21.65 \%)$. Characterizing IH, which were eliminated by this method - it was only small (5-6 cm in diameter), isolated epigastric by localization (M1) hernia after a history of laparotomies.

In the period from 2010 to 2017, the technique of patient's own tissue hernioplasty (OTHP) was used in 
$124(15.08 \%)$ patients. The decrease in the number of this type of operation by 2.53 times compared with the comparison group is due to the wider introduction into surgical practice of alloplastic techniques. The largest proportion of autoplastics performed in the main group was in patients with umbilical hernia 67 (54.03\%). Other localizations of PVH in this observation period were mainly eliminated by implantation methods. In 27 (21.78 $\%)$ people with IH due to the high comorbidity index (6 and above) and intra- and postoperative risk of general complications (pulmonary embolism, myocardial infarction, acute cerebrovascular disorders) in which there was a small and mostly medium by localization, the ventral hernia was performed using OTHP, mostly with a continuous prolene suture.

Alloplastic methods of surgical treatment in the comparison group were used in $283(47.40 \%)$ patients, in the main group - in $678(82.48 \%)$ patients. In the period from 2001 to 2009 , among the alloplastic methods, the "onlay" method significantly prevailed - 254 (89.75\%). Methods such as "inlay" and "sublay" were used only in $17(6.00 \%)$ and $12(4.24 \%)$ cases, respectively.

In the first observation period (2001-2009), the "onlay" method was most often used due to the imperfect surgical technique of performing the "sublay" and "CST" methods. On the other hand, patients with second or more recurrence of $\mathrm{IH}$ with pronounced scarring of the anterior abdominal wall in the area of the hernia defect, did not allow to perform another type of surgery.

However, despite the widespread introduction in 2010 of the method of "sublay" and "CST", the number of performed surgeries on the type of "onlay" decreased, but remained at $209(30.83 \%)$, that is almost every third patient, due to technical simplicity and the safety of this method.

In the comparison group, abdominal compartment syndrome (ACS) developed in $9(3.54 \%)$ patients due to the fact that large hernias in the period from 20012009 were mainly eliminated by the "onlay" method. Whereas in the period from 2010, patients with a high comorbidity index with a ventral hernia (W2 and more) underwent surgery such as "sublay" or "CST". In cases of lack of technical capabilities to perform these types of surgical interventions, the method of choice was the operation "onlay" supplemented by resection of the large omentum and intraoperative monitoring of intraabdominal pressure. As a result, in the main group after performed allohernioplasty according to this method ACS was not observed.

To reduce the number of wound complications in the early postoperative period, we improved the technique of performing the technique "onlay" by using bipolar electrocoagulation with constant irrigation of the wound surface with a cold solution of antiseptic, which creates reliable hemostasis with minimal adverse effects of thermal energy coagulator.

To reduce the exudative reaction and, as a consequence, the formation of inflammatory infiltrates and suppurations, a method of alloplasty of ventral hernias (patent of Ukraine No. 56938A) was used, in which before the operation, a mesh allograft treated with a liposomal complex with an antibacterial and immunosuppres- sive agent included in it was fixed on top of the suture line according to the "onlay" method.

The "inlay" technique was performed in a total of $107(7.54 \%)$ people. This method in most cases was used by us in the absence of technical possibility of tension and erection of the edges of the aponeurosis in the area of the hernia defect, a high risk of cardiopulmonary complications. We considered this method as a "palliative" surgical intervention in elderly and senile patients. The lack of tissue tension when performing this method of hernioplasty caused the lack of development of ACS in the postoperative period in both periods of the research.

The "sublay" technique undoubtedly corresponds to the principle of reconstructive surgery for surgical treatment of $\mathrm{PVH}$ and $\mathrm{POVH}$ and is a basic technique.

In the first period (2001-2009), the "sublay" operation in the variant of subponeurotic location of polypropylene meshes (PPM), as is typical for this period of research of "heavy" PPM, was performed in $41.67 \%$ of persons, and according to the functional results of the remote postoperative period it was similar to the "onlay" technique. There was marked atrophy of the rectus abdominis, which could be the cause of the recurrence. Intermuscular placement, which was used only in patients with lumbar hernias in both groups (16.66 \% and $4.80 \%$, respectively), gave $100 \%$ recurrence in the control group.

Regarding the type of mesh implant used, in the period from 2001 to 2009 only "heavy" PPMs were used. Since 2010, we have introduced a wider use of "light" PPM: "light" - in 215 (68.91 \%), "light" + PRFmembrane - in 54 (17.31\%), "heavy" - in 43 (13.78\%) patients.

According to our biochemical researches, it was stated that the best results of connective tissue metabolism in the levels of oxyproline, cryoglobulins and glycosaminoglycan; reduction of endothelial dysfunction; moderate local and general immune strain was observed in a group of patients who were implanted with "light" PPM in combination with a PRF-membrane. These data are confirmed by the morphological picture: at the microscopic and electron microscopic levels we revealed significantly reduced manifestations of the inflammatory response, improved microcirculation in the area of implantation of a "light" mesh with a PRF- membrane. This helped to increase the activity of fibroblasts and the formation of collagen fibers around the mesh material. There was a decrease in the number of local complications that are predictors of recurrence.

PRF (Platelet-Rich Fibrin) is a platelet concentrate enriched with growth factors and stem cells. It was first developed in 1970 by Mattress. This fibrin matrix technology became a leader in "regenerative medicine" and became widely used in dental orthopedic practice. In hernia surgery, this technique was used by us for the first time.

The application of the proposed method (positive decision to grant a patent for a utility model No. 31772 of December 12, 2018) helped reduce early postoperative complications by $17.56 \%$ and reduce the number of recurrences by $23.15 \%$ in patients with high risk 
of local postoperative complications, as well as in the treatment of POVH in young patients with undifferentiated connective tissue dysplasia syndrome.

Among other technical improvements that significantly improved the safety of the "sublay" technique was the method of fixing the polypropylene mesh when performing retromuscular allohernioplasty (Ukrainian patent for utility model No. 123752). The application of this improvement contributed to a more reliable fixation, uniform stretching of the PPM under the muscles with the absence of additional protrusions, which eliminates the possibility of formation of seromas and separationrejection of the mesh with the formation of cysts.

The next technical improvement in allohernioplasty "sublay" was the method of fixing the polypropylene mesh under the conditions of the variant of retromuscular allohernioplasty (Ukrainian patent for utility model No. 123341). Before suturing the posterior sheets of the rectus vagina with the abdomen open under visual control, we apply several prolene sutures to the posterior sheet of the rectus vagina to which we fix the PPM.

To optimize the treatment of PVH and IH by "sublay" technique in patients with high comorbidity index and high anesthesia-surgical risk (ASA III) to reduce trauma and decrease the duration of surgery, we proposed a method of fixing PPM when performing retromuscular allohernioplasty surgical glue "Katsil" (Ukrainian patent for utility model No. 123340).

Surgical interventions of anatomical components separation of anterior abdominal wall (CST) by Ramirez were used in our research in $45(3.17 \%)$ patients with large and giant POVH (W3 and larger). 25 (1.76\%) patients underwent the combined method of surgery (CST + PPM). Among patients of older age groups in whom there was a moderately high comorbidity index (4-6), which allowed to expand the volume and, as a consequence, the duration of surgery, this type of combined allohernioplasty was performed in $10(22.22 \%)$ and $715.56 \%)$ patients, respectively. In $20(44.44 \%)$ patients with a high comorbidity index (6 or more) this technique was performed without the use of PPM.

Optimization of surgical treatment of PVH and POVH was carried out by extensive implementation of the program of rapid recovery after surgery (Enhanced Recovery After Surgery) and own improvements in surgical techniques to perform basic alloplastic methods of hernioplasty.

Conclusions. 1. These features of the dynamics of the used methods of surgical interventions and types of polypropylene meshes in an individualized approach to each individual patient were reflected in a significant reduction in the number of both early local and general and late postoperative complications, which improved the effectiveness of surgical treatment of patients with primary postoperative ventral hernias.

2. The application of the developed set of measures aimed at preventing postoperative complications and improving the safety of surgical interventions, improvement and introduction of new techniques for allohernioplasty, reduced the incidence of early local postoperative complications from $52.09 \%$ to $25.67 \%$, and general complications from $10.0 \%$ to $2.80 \%$ (p $<0.05)$. The postoperative mortality rate decreased from
$2.01 \%$ to $0.24 \%(\mathrm{p}<0.05)$. Recurrence of hernias decreased from $22.11 \%$ to $4.71 \%(\mathrm{p}<0.05)$.

\section{References:}

1. Petrov DYu, Kovalev AI, Smirnov AV. Differentiated approach to the choice of the method of allogeneoplasty. Aktualnyie voprosyi gerniologii. Moscow; 2013. P.119-121. (in Russian)

2. Polovyj VP, Vlasov VV, Arseniuk VV. Dysplasia of connective tissue, as a predictor of occurrence of anterior abdominal hernia: monograph. Chernivtsi; 2016. P.288. (in Ukrainian)

3. Piatnochka VI. Determination of specific simptoms of non-differentiated dysplasia of connecting tissue in patients with postoperative ventral hernia with the substantiation of the choosing the optimal method of operational intervention and prosthesis type. Shpytalna khirurhiya. 2017; 2:43-49. (in Ukrainian)

4. Feleshtynskyi YaP. Modern methods of surgical treatment following surgical hernia. Zdorovia Ukr. 2016. P.24-27. (in Ukrainian)

5. Helgstrand F. National results after ventral hernia repair. Dan Med J. 2016; 63(7):52-58.

6. Israelsson LA, Millbourn D. Prevention of incisional hernias: How to close a midline incision. Surg Clin North Am. 2013; 93(5):1027-1040.

7. Kaoutzanis C, Leichtle S, Mouawad N. Risk factors for postoperative wound infections and prolonged hospitalization after ventral/incisional hernia repair. Hernia. 2015; 19(1):113-123.

8. Köhler G, Luketina R, Emmanuel K. Sutured repair of primary small umbilical and epigastric hernias: Concomitant rectus diastasis is a significant risk factor for recurrence. World J Surg. 2015; 39(1):121126.

9. Muysoms F, Antoniou S, Bury K. European hernia society guidelines on the closure of abdominal wall incisions. Hernia. 2015; 19(1):1-24.

10. Oodit R. Hernia surgery, South Africa 2015: Editorial. South African Journal of Surgery. 2015; 53(2):37.

11. Patel PV, Merchant AM. Ventral hernia repair in the morbidly obese patient: A review of medical and surgical approaches in the literature. Bariatr Surg Pract Patient Care. 2014; 9(2):61-65.

12. Ross SW, Wormer BA, Kim M. Defining surgical outcomes and quality of life in massive ventral hernia repair: An international multicenter prospective study. Am J Surg. 2015; 210(5):801-813.

УДК 617.55-003.92-007.43-089

ПОВЫШЕНИЕ БЕЗОПАСНОСТИ ОПЕРАЦИОННЫХ ВМЕШАТЕЛЬСТВ У БОЛЬНЫХ НА ВЕНТРАЛЬНУЮ И ПОСЛЕОПЕРАЦИОННУЮ ГРЫЖУ В УСЛОВИЯХ КОМОРБИДНОСТИ ПРИ ВЫПОЛНЕНИИ РАЗЛИЧНЫХ ТИПОВ ОТКРЫТЫХ ГЕРНИОПЛАСТИК

\section{В.И. Пятночка, И.Я. Дзюбановский, А.М. Продан}

Тернопольский нащчональный медицинский университет имени И.Я. Горбачевского МОЗ Украины, 
кафедра хирургии НИИ ПО,

2. Тернополь, Украина,

ORCID ID: 0000-0002-7417-4797,

ORCID ID: 0000-0001-8852-3938,

ORCID ID: 0000-0002-6052-192X,

e-mail:vladymyrpiatnochka@gmail.com

Резюме. Вопрос лечения пациентов с первичной и послеоперационной грыжей остается одной из актуальных проблем абдоминальной хирургии. Совершенствование хирургической техники и внедрение новых способов выполнения герниопластики и в дальнейшем сопровождается значительным количеством осложнений в послеоперационном периоде, особенно на фоне выраженной коморбидности.

Цель работы: проанализировать результаты хирургического лечения больных с первичными и послеоперационными вентральными грыжами на фоне выраженой коморбидности и разработать технические предпосылки повышения безопасности выполнения операционных вмешательств.

Материалы и методы. Проведено углубленное комплексное клинико-инструментальное и лабораторное обследование в период с 2001 по 2017 год, 1419 больных с первичной и послеоперационной вентральной грыжей. Распределение пациентов на группы происходило в соответствии с периодами хирургического лечения больных. В первом периоде обследовано и прооперировано 597 больных. Эти пациенты составили группу сравнения. Основную группу составили пациенты, прооперированные в период с 2010 по 2017 год - 822 человек.

Результаты исследования. Оценку результатов исследования в обеих группах наблюдения проводили с учетом частоты общих и местных раневых осложнений и рецидивов в отдаленном послеоперационном периоде. Из всех 1419 оперированных пациентов местные ранние послеоперационные осложнения диагностированы у 522 (36,78\%) человек. Общие осложнения были у 76 (5,36\%) пациентов.

Выводы. Применение разработанного комплекса мероприятий, направленных на предупреждение развития послеоперационных осложнений и повышения безопасности операционных вмешательств, совершенствование и внедрение новых технических приемов при алогерниопластике, позволило снизить частоту ранних местных послеоперационных осложнений с 52,09\% до 25,67\%, а общих осложнений с $10,05 \%$ до 2,80\%. Уровень послеоперационной летальности снизился с 2,01\% до 0,24\%. Рецидивирование грыж уменьшилось с 22,11\% до 4,71\%.

Ключевые слова: первичная вентральная грыжа, послеоперационная вентральная грыжа, осложнения, хирургическое лечение, коморбидность.

\author{
УДК 617.55-003.92-007.43-089 \\ ПІДВИЩЕННЯ БЕЗПЕКИ ОПЕРАЦІЙНИХ \\ ВТРУЧАНЬ У ХВОРИХ НА ВЕНТРАЛЬНУ ТА \\ ІНЦІЗІ̆ННУ ГРИЖУ ЗА УМОВ
}

\section{КОМОРБІДНОСТІ ПРИ ВИКОНАННІ РІЗНИХ ТИПІВ ВІДКРИТИХ ГЕРНІОПЛАСТИК.}

\author{
В.I. П’ятночка, І.Я. Дзюбановський, А.М. Продан
}

Тернопільський національний медичний університет імені І.Я. Горбачевського МОЗ Украӥни, кафедра хірургії ННІ ПО,

м. Тернопіль, Украӥна,

ORCID ID: 0000-0002-7417-4797,

ORCID ID: 0000-0001-8852-3938,

ORCID ID: 0000-0002-6052-192X,

e-mail:vladymyrpiatnochka@gmail.com

Резюме. Питання лікування пацієнтів на первинну вентральну та інцізійну грижу на сьогодні залишається однією 3 актуальних проблем абдомінальної хірургії. Удосконалення хірургічної техніки та запровадження нових способів виконання герніопластики і надалі супроводжується значною кількістю ускладнень в післяопераційному періоді, особливо на фоні вираженої коморбідності.

Мета роботи: проаналізувати результати хірургічного лікування хворих 3 коморбідними станами на первинні та інцізійні вентральні грижі та виробити технічні передумови підвищення безпеки виконання операційних втручань.

Матеріали і методи. Проведено поглиблене комплексне клініко-інструментальне та лабораторне обстеження в період з 2001 по 2017 рр. 1419 хворих на первинну вентральну та інцізійну грижу. Розподіл пацієнтів на групи відбувався відповідно до періодів хірургічного лікування хворих. У першому періоді обстежено та прооперовано 597 хворих. Ці пацієнти склали групу порівняння. Основну групу, що відповідала пацієнтам, які були прооперовані в період з 2010 по 2017 рр. склали 822 осіб.

Результати дослідження. Оцінку результатів дослідження в обох групах спостереження проводили iз врахуванням частоти загальних і місцевих ранових ускладнень та рецидивів у віддаленому післяопераційному періоді. 3 усіх 1419 оперованих пацієнтів місцеві ранні післяопераційні ускладнення діагностовано у 522 (36,78 \%) осіб. Загальні ускладнення були у $76(5,36 \%)$ пацієнтів.

Висновки. Застосування розробленого комплексу заходів, направлених на попередження післяопераційних ускладнень і підвищення безпеки операційних втручань, удосконалення i запровадження нових технічних прийомів при алогерніопластиці дозволило знизити частоту ранніх місцевих післяопераційних ускладнень $352,09 \%$ до 25,67 \%, а загальних ускладнень 3 10,05 \% до 2,80 \%. Рівень післяопераційної летальності зменшився 3 2,01\% до 0,24\%. Рецидивування гриж зменшилося з 22,11 \% до 4,71\%.

Ключові слова: вентральна грижа, інцізійна грижа, ускладнення, хірургічне лікування, коморбідність. 